европейский интеграционный процесс.

Ключевые слова: договор, договорно-правовая база, двустороннее сотрудничество, украинский-польские отношения, региональное сотрудничество, Республика Польша, Украина.

Horot A. Development of Regional Cooperation between Ukraine and the Republic of Poland: the Contractual Base Genesis. Modern international relations are characterized by intensive integration processes, among which cross-border, regional, and interregional cooperation plays an important role. Ukraine, due to its favorable geopolitical position, has great potential for its development. However, the process of inter-state relations formation has a number of specific features. Throughout the time of independent Ukraine, regional cooperation has been formed under the influence of a number of factors, both external and internal, which made a significant impact on these processes. A retrospective review of these relations genesis shows that their formation is a complex and contradictory process, although the tendency towards understanding and rapprochement between the two neighboring states has always dominated in it. The legislative framework for regional relations between Ukraine and the Republic of Poland has come much closer to the best European standards since the second half of the 1990s. Although a lot of things need to be done in Ukraine to complete the formation of a national legislative framework, which would fully define the legal framework and regulate regional cooperation. In particular, the fact is that even after 1996, when the «Carpathian» and «Bug» Euroregions began to function, no law of Ukraine defined the categorical apparatus according regional cooperation and the peculiarities of the functioning of the border region in the foreign market. From a political point of view, maintaining a high level of cross-border relations between Ukraine and Poland, and Ukraine in general, contributed to the formation of pro-market, pro-Western orientation of Ukrainian society, which had a positive impact on the entire European integration process.

Key words: agreement, legal framework, bilateral cooperation, Ukrainian-Polish relations, regional cooperation, Republic of Poland, Ukraine.

УДК 340.12

DOI https://doi.org/10.32782/2409-4544/2020-1/7

М. Копетюк

\title{
Поняття та класифікація міжнародних стандартів прав людини та громадянина
}

Стаття присвячена дослідженню правової основи міжнародних стандартів прав і свобод людини та громадянина. Проаналізовано наукові підходи до визначення поняття міжнародних стандартів прав людини і громадянина, а також розглянуті питання забезпечення прав і свобод людини і громадянина відповідно до міжнародних стандартів, закріплених в міжнародно-правових документах. Здійснено аналіз міжнародно-правових актів, які містять відповідні стандарти в сфері дотримання прав людини і громадянина, а також розглянуто їх класифікацію. Міжнародні стандарти прав людини є системою прав, які розкривають сучасну ідею прав людини, закріплену в основних міжнародно-правових документах і, відповідно, визнану в усьому світі. Стандарти основних прав $\mathrm{i}$ свобод людини і громадянина регулюються низкою міжнародно-правових актів, що визначають політичні, природні, культурні, соціальні права. Автор зробив висновок про те, що у основу Конституції України закладено принципово нові правові парадигми зовнішньої і внутрішньої державної політики України, що спрямовані на утвердження й забезпечення прав і свобод людини i громадянина. А це об'єктивно вимагає істотної переорієнтації та модифікації всієї національної правової системи. В Україні набуває поширення теорія визнання людської гідності, яка $\epsilon$ інтегративною властивістю природи людини та виступає як один з інституційних джерел ії основних прав. I з огляду на це у загальній теорії права сформульовано антропогенну інтерпретацію людської гідності, поняття якої визначається як самоцінність людини як унікальної біосоціальної істоти. На переконання автора, зазначені доктринальні позиції у ближній перспективі вимагатимуть відповідної

(C) Копетюк M., 2020 
нормативно-правової і навіть конституційної регламентації. Адже держава має охороняти, захищати права і свободи людини та громадянина, гарантувати їх реальне здійснення. Відповідно, держава повинна створювати необхідні умови для гідної праці, надавати соціальну допомогу тим, хто перебуває у складних життєвих обставинах.

Ключові слова: права і свободи людини та громадянина, міжнародні стандарти прав людини та громадянина, класифікація міжнародних стандартів прав людини та громадянина.

Постановка наукової проблеми та її значення. Із здобуттям Україною незалежності, та проголошення іiї соціальною, правовою державою, а також з врахуванням того, що у сучасному світі визнання, дотримання, захист прав і свобод людини та громадянина $є$ одним із найважливіших обов'язків держави, Україна як суб'єкт міжнародного права, одна із засновниць ООН, проводить активну роботу, спрямовану на використання не тільки національних, а й міжнародних інститутів захисту прав і свобод людини та громадянина.

У XXI ст. світ перебуває в стані постійної модернізації, гармонізації інтересів держав і народів, безпрецедентного розширення інформаційного простору і необхідності адаптації до постійно мінливих життєвих умов. У подібній ситуації дотримання права кожної людини на розвиток $\epsilon$ невід'ємною і вкрай важливою складовою стабільності.

Міжнародно-правові стандарти $є$ результатом тривалої роботи великої кількості держав 3 вироблення узгоджених позицій в області прав людини. Держави спрямовують свою діяльність на дотримання певних універсальних цінностей, забезпечуючи повагу і захист прав людини всіма доступними способами. Вони відповідальні за виконання своїх зобов'язань в галузі прав і свобод людини перед своїм населенням і міжнародним співтовариством. А тому визнання, дотримання, захист прав та свобод людини і громадянина є одним із найважливіших обов'язків держави.

Аналіз досліджень цієї проблеми. Аналіз останніх досліджень і публікацій щодо проблематики світового розвитку захисту і дотримання основних прав та свобод людини і громадянина перестали бути компетенцією конкретно взятої країни, а стали справою всього міжнародного співтовариства, оскільки вони є важливішим правовим завданням сьогодення багатьох держав цього співтовариства. А тому дослідження правової основи міжнародних стандартів прав та свобод людини і громадянина, аналіз підходів щодо визначення поняття міжнародних стандартів прав людини і громадянина, забезпечення цих прав і свобод, відповідно до міжнародних стандартів, закріплених у міжнародно-правових документах, є надто важливим і досить актуальним питанням сьогодення. Дане питання є об'єктом досліджень досить широкого кола науковців, серед яких Ю. Ю. Білас, С. А. Голубок, О. Я. Гораджаєв, В. М. Косович, С. М. Ляхівненко, С. М. Оганесян, Н. М. Раданович, О. І. Тіунов, В. Я. Тацій, Ю. Н. Тодика та інші. На сьогодні ця проблема не $є$ вичерпаною, що й обумовило вибір теми.

Формулювання мети та завдань статті. Мета статті полягає у теоретичному аналізі підходів щодо визначення поняття та класифікація міжнародних стандартів прав і свобод людини та громадянина, забезпечення цих прав і свобод, відповідно до міжнародних стандартів, закріплених у міжнародно-правових документах.

Виклад основного матеріалу й обгрунтування отриманих результатів дослідження. Права людини - це соціальна спроможність людини вільно діяти, самостійно обирати вид та міру своєї поведінки з метою задоволення своїх різнобічних матеріальних та духовних потреб шляхом користування певними соціальними благами в межах, визначених законодавчими актами [11, с. 12].

Міжнародно-правові стандарти є результатом тривалої роботи великої кількості держав 3 вироблення узгоджених позицій в області прав людини. Держави спрямовують свою діяльність на дотримання певних універсальних цінностей, забезпечуючи повагу і захист прав людини всіма доступними способами. Вони відповідальні за виконання своїх зобов'язань в галузі прав та свобод людини і громадянина перед своїм населенням і міжнародним співтовариством. На сьогодні, коли проблема прав людини вийшла далеко за межі окремої держави, виникла необхідність у створенні універсальних міжнародно-правових стандартів, які також визнаються як основні права людини. Ці стандарти відображені у низці важливих міжнародно-правових актів, що встановили загальнолюдські стандарти прав та інтересів особи, визначивши ту межу, за яку держава не може виходити.

Міжнародні стандарти у сфері прав людини складалися поступово. Спочатку були закріплені лише парламентські і політичні права, потім - економічні та соціальні. Ці стандарти складаються із сукупності відповідних принципів та норм, що насамперед встановлюють: права та свободи людини в різноманітних сферах життєдіяльності; обов'язки держави із забезпечення та дотримання прав людини без будь-якої дискримінації як у мирний час, так і у період збройних конфліктів; загальні 
принципи природного права; відповідальність за злочинне порушення прав людини; напрями розвитку та розширення сфери прав людини; напрями посилення контрольного механізму за виконанням державами взятих на себе зобов'язань у сфері прав людини. I на їх основі кожна держава зобов'язана упорядкувати чинне законодавство, усунути протиріччя з нормами міжнародного права, відмінити застарілі норми, ліквідувати прогалини.

Нині у Європі інститут основних прав і свобод людини існує не тільки на національному, а й наднаціональному рівні, тобто в рамках Європейського Союзу в цілому [7, с. 2]. Він є сукупністю норм права ЄС, які закріплюють найбільш важливі, спільні для всього Союзу стандарти у сфері захисту основних прав і свобод людини, а також принципи взаємовідносин особистості $з$ органами публічної влади на всіх рівнях. Питання прав і свобод людини та громадянина на сьогодні $€$ найважливішою проблемою внутрішньої та зовнішньої політики всіх держав світової співдружності. Саме стан справ у сфері забезпечення прав і свобод особи, їх практичної реалізації $є$ одним із основних критеріїв, за яким оцінюється рівень демократичного розвитку будь-якої держави.

Міжнародні стандарти прав людини є системою прав, що розкриває сучасну ідею прав людини, закріплену в основних міжнародно-правових документах i, відповідно, визнану в усьому світі. Стандарти основних прав і свобод людини та громадянина регулюються низкою міжнародноправових актів, що визначають політичні, природні, культурні, соціальні права. Тому, вирішення питання про міжнародні стандарти Щодо основних прав, свобод і обов’ язків, їх захисту є актуальним напрямом сучасної правової науки. Зазначеному сприяють положення Основного закону нашої держави - Конституції України [7, с. 2], згідно з якими «чинні міжнародні договори, згода на обов'язковість яких надана Верховною Радою України, є частиною національного законодавства України» (ст. 9), а також визначення зовнішньої політичної діяльності України як такої, що «спрямована на забезпечення іiі національних інтересів і безпеки шляхом підтримання мирного i взаємовигідного співробітництва 3 членами міжнародного співтовариства за загальновизнаними принципами і нормами міжнародного права» (ст. 18) [3]. Варто відзначити, що і положення ст. 3 Конституції України деталізуються в численних статтях їі Розділу II «Права, свободи і обов’язки людини і громадянина», норми якого не можна розглядати поза зв'язком із принципом визнання людини, іiі прав і свобод як найвищої цінності, i, звичайно, не можна вносити в них зміни та доповнення, які суперечать даному принципу.

Серед найважливіших загальних документів, 3 якими повністю узгоджуються положення Конституції України, - Загальна декларація прав людини (1948р.), Міжнародний договір про громадянські та політичні права (1966р.), Міжнародний договір про економічні, соціальні та культурні права (1966 р.), Європейська конвенція про захист прав та фундаментальних свобод людини 3 протоколами (1950р.), Свропейський соціальний статут (1961р.), Заключний акт Наради 3 питань безпеки та співробітництва в Свропі (1975р.), Підсумковий документ Віденської зустрічі представників держав-учасниць Наради 3 питань безпеки та співробітництва в Європі (1989 р.) [1, c. 13-15].

Але, нині одним з найважливіших міжнародних актів із захисту прав людини та громадянина є Загальна декларація прав людини прийнята Генеральною Асамблеєю ООН 10 грудня 1948 р. День прийняття Декларації відзначається щорічно як Всесвітній день прав людини. У ній закріплений широкий перелік громадянських, політичних, соціально-економічних і культурних прав. У тексті документа відображений природний характер прав людини, зокрема, в ст. 1 зазначається: «Всі люди народжуються вільними і рівними у своїй гідності та своїх правах» [4]. Більшість держав світу, у тому числі й Україна, вмістили посилання на Загальну декларацію прав людини або ії положення у свої конституційні акти.

3 огляду на подальшу демократизацію в Україні процесу захисту прав і свобод людини у ст. 55 Конституції України записано, що кожен має право після використання всіх національних засобів правового захисту звертатися за захистом своїх прав і свобод до відповідних міжнародних судових установ чи до відповідних органів міжнародних організацій, членом або учасницею яких є Україна. Такими органами є Комітет 3 прав людини ООН, Європейський суд 3 прав людини, а також Свропейська комісія з прав людини. Склад і порядок діяльності вказаних судів визначаються у розділах II, III i IV Свропейської конвенції про захист прав та основних свобод людини.

Слід погодитись 3 думкою окремих науковців і відмітити, що незважаючи на те, що в Україні прийнято демократичне законодавство у сфері прав і свобод людини, однак в умовах соціальноекономічної і політичної кризи, падіння культури і моралі є відсутніми ефективні механізми захисту цих прав, що призводить до їх масових і систематичних порушень, а іноді просто до неможливості їх реалізації. Для побудови в Україні демократичної правової держави суттєве значення має боротьба 3 
правовим нігілізмом, з правовим інфантилізмом, феноменом переродження правосвідомості, який одержує свій прояв, насамперед, у злочинності [6, с. 43]. Безумовно усі ці форми деформації правосвідомості не сприяють становленню демократичної правової культури, зорієнтованої на цінності конституціоналізму. Особливе значення тут має викорінення організованої злочинності, корупції, які суттєво підривають віру громадян у право і закон, здатність влади навести у країні правопорядок. Розвиток тіньової економіки, беззаконня, правове свавілля - це суттєві чинники розвитку правового нігілізму, інших форм деформації правосвідомості, з якими необхідно рішуче боротися на основі чітко визначеної державної політики у сфері правового виховання і юридичної освіти населення, наведення порядку в усіх сферах суспільного життя.

I все ж, не менш важливою проблемою є недоліки в самому законодавстві: недостатньо розроблені юридичні механізми реалізації і захисту тих чи інших прав і свобод, між ними існують певні внутрішні суперечності. Наприклад, чинне законодавство України про місцеве самоврядування потребує суттєвого вдосконалення з метою забезпечення пріоритетності прав людини і громадянина в організації і діяльності органів місцевого самоврядування; розширення кола суб'єктів права на участь у місцевому самоврядуванні; розбудови повноважень органів місцевого самоврядування у фінансовобюджетній сфері, дійсної реалізації принципу формування державного бюджету «знизу», збільшення долі місцевих бюджетів у консолідованому загальнодержавному бюджеті 3 метою зміцнення матеріально-фінансової бази місцевого самоврядування. Цьому сприятиме закріплення та розширення повноважень місцевого самоврядування у сфері розвитку і підтримки малого та середнього підприємництва, працевлаштування місцевих жителів. Потребує також вирішення й питання створення системи органів адміністративної юстиції для правового захисту місцевого самоврядування, прав і свобод людини і громадянина в сучасних умовах державотворення. Тільки вирішивши ці проблеми, ми наблизимося до побудови правової держави, в якій права і свободи особи дійсно виступають головним напрямом іï функціонування.

Аналізуючи існуючу в Україні систему гарантій прав і свобод особи можна дійти висновку про практично необмежене коло засобів захисту прав і свобод людини і громадянина з боку держави та інституцій громадянського суспільства, але, 3 іншого боку, існує проблема незадовільної гарантованості практичної реалізації охорони і захисту окремих прав і свобод особи. Насамперед, це стосується соціально-економічних прав і свобод, закріплених і гарантованих чинною Конституцією України. Слід констатувати, що поки вони фактично мають більше декларативний, ніж реальний характер, переважно проголошені, аніж гарантовані. Важливою причиною наявних проблем у галузі реалізації прав і свобод $є$ те, що юридичні норми, які стосуються прав і свобод особи, об'єктивно не відповідають фактичним соціальним можливостям, які вони опосередковують. Через економічні проблеми держава фактично не спроможна забезпечити і гарантувати всім громадянам більшість проголошених у Конституції України соціальних і економічних прав і свобод.

Висновки. Підсумовуючи викладене і даючи деякі пропозиції, зауважимо, що, безумовно, в основу Конституції України закладено принципово нові правові парадигми зовнішньої і внутрішньої державної політики України, що спрямовані на утвердження й забезпечення прав і свобод людини i громадянина. А це об'єктивно вимагає істотної переорієнтації та модифікації всієї національної правової системи.

Однак, необхідно вважати й на те, що нині в Україні набуває поширення теорія визнання людської гідності, яка $\epsilon$ інтегративною властивістю природи людини та виступає як один 3 інституційних джерел іï основних прав. I з огляду на це у загальній теорії права сформульовано антропогенну інтерпретацію людської гідності, поняття якої визначається як самоцінність людини як унікальної родової біосоціальної істоти. На наше переконання, зазначені доктринальні позиції у ближній перспективі вимагатимуть відповідної нормативно-правової i навіть конституційної регламентації.

Тому що держава має визнавати людину найвищою соціальною цінністю, легалізувати, легітимізувати, охороняти, захищати іiі права і свободи, гарантувати їх реальне здійснення. А звідси, вона повинна створювати для неї всі необхідні умови для гідної праці, надавати соціальну допомогу тим, хто перебуває у складних життєвих обставинах і т. i.

\section{Джерела та література}

1. Гораджаєв О. Я. Конституційні права і свободи людини і громадянина в країнах Співдружності Незалежних Держав і міжнародно-правові стандарти: автореф. дис. ... канд. юрид. наук /О. Я. Гораджаєв. - Одеса,1998. - 22 с. 
2. Загальна декларація прав людини від 10 рудня 1948 року // Офіційний вісник України. - 2008. № 93 [Електронний pесурс]. - Режим доступу: http://kr-admin.gov.ua/mol/molod/2.pdf.

3. Закон України «Про міжнародні договори України» від 29.06.2004 р. / Відомості Верховної Ради України. - 2004. - № 50. - Ст. 540.

4. Конституція України від 28.06.1996 р. / Відомості Верховної Ради України. - 1996. - № 30.Ст. 141.

5. Рабінович П. М. Моральна шкода та право на їі компенсацію: загальнотеоретичний підхід / П. М. Рабінович // Право України. - 2002. - № 4. - С. 100-103.

6. Тодыка Ю. Н. Конституционные основы формирования правовой культуры / Ю. Н. Тодыка. - Х.: Райдер, 2001. - 160 с.

7. Шевчук С. Судовий захист прав людини: Практика Свропейського суду з прав людини у контексті західної правової традиції. Київ: Реферат, 2006. - 848 с.

Копетюк Н. Понятие и классификация международных стандартов прав человека и гражданина. Статья посвящена исследования правовой основы международных стандартов прав и свобод человека и гражданина. В ней проанализированы подходы к определению понятия международных стандартов прав человека и гражданина, а также рассмотрены вопросы обеспечения прав и свобод человека и гражданина в соответствии с международными стандартами, закрепленными в международно-правовых документах. Осуществлен анализ международноправовых актов, которые содержат соответствующие стандарты в области соблюдения прав человека и гражданина, а также рассмотрена их классификация. Международные стандарты прав человека является системой прав, которые раскрывает современную идею прав человека, закрепленную в основных международно-правовых документах и, соответственно, признанную во всем мире. Стандарты основных прав и свобод человека и гражданина регулируются рядом международноправовых актов, определяющих политические, естественные, культурные, социальные права. Автор сделал вывод о том, что в основу Конституции Украины заложены принципиально новые правовые парадигмы внешней и внутренней государственной политики Украины, направленные на утверждение и обеспечение прав и свобод человека и гражданина. А это объективно требует существенной переориентации и модификации всей национальной правовой системы. В Украине получает распространение теория признания человеческого достоинства, которое является интегративным свойством природы человека и выступает как один из институциональных источников его основных прав. И в связи с этим в общей теории права сформулировано антропогенную интерпретацию человеческого достоинства, понятие которого определяется как самоценность человека как уникального биосоциального существа. По мнению автора, указанные доктринальные позиции в ближней перспективе будут требовать соответствующей нормативноправовой и даже конституционной регламентации. Ведь государство обязано охранять, защищать права и свободы человека и гражданина, гарантировать их реальное осуществление. Соответственно, государство должно создавать необходимые условия для достойного труда, оказывать социальную помощь тем, кто находится в сложных жизненных обстоятельствах.

Ключевые слова: права и свободы человека и гражданина, международные стандарты прав человека, классификация международных стандартов прав человека.

Kopetiuk M. The International Human and Civil Rights Standards: Concept and Classification. The article focuses exclusively on the legal basis of the international standards of human and civil rights and freedoms. The author highlights the approaches to defining the concept of international standards of human and civil rights and the issue of ensuring human and civil rights and freedoms in accordance with the international standards enshrined in international legal instruments. The analysis of international legal acts that contain relevant standards in the field of human and civil rights, as well as their classification, are of great importance. International human rights standards are a system of rights based on the modern idea of human rights, enshrined in fundamental international legal documents, and admitted worldwide. Standards of fundamental human and civil rights and freedoms are governed by a number of international legal acts, determining political, natural, cultural, and social rights. The author concluded that the Constitution of Ukraine is based on fundamentally new legal paradigms of foreign and domestic state policy of Ukraine, which are aimed at establishing and ensuring the rights and freedoms of person and citizen. And this objectively requires a significant reorientation and modification of the entire national legal system. In Ukraine, the theory of recognition of human dignity is becoming widespread, which is an integrative property of human nature and acts as one of the institutional sources of its fundamental rights. 
And according this, the general theory of law formulates an anthropogenic interpretation of human dignity, the concept of which is defined as the self-worth of person as a unique biosocial being. In our opinion, these doctrinal positions in the near future will require appropriate legal and even constitutional regulation. Because the state must protect, defend rights and freedoms, guarantee their actual implementation. And also the state must create all the necessary conditions for decent work, provide social assistance to those who are in difficult life circumstances.

Key words: human and civil rights and freedoms, international human rights standards, classification of international human rights standards.

УДК 347.962 .3

DOI https://doi.org/10.32782/2409-4544/2020-1/8

В. Кравчук

\section{Громадянські (особисті) права суддів як елемент їх конституційної правосуб'єктності}

У статті досліджено права і свободи суддів, які втілюють сутність і зміст правового зв'язку судді з судами. Права суддів пропонується розглядати як вид і міру їх можливої або дозволеної поведінки, встановлені нормами права для реалізації їх функцій і завдань та забезпечуються державою. Автор вважає дискусійною позицію про те, що права суддів виникають виключно 3 моменту призначення на посаду судді. Деякі права (наприклад, право на повагу до гідності або право на результати творчої та інтелектуальної діяльності) належать громадянину і до призначення його на посаду судді, і після припинення суддівської діяльності. Однак після призначення на посаду судді вищевказані права набувають нового змісту і забезпечуються дещо іншими засобами державного примусу. У зв'язку з цим права суддів можна розділити на загальні і спеціальні. До загальних відносяться ті права, які належать судді як людині і громадянину, але після вступу у відповідний правовий статус змінюють зміст, порядок реалізації та забезпечення. До спеціальних належать права, які в науковій літературі прийнято називати посадовими, тобто пов'язані зі здійсненням правосуддя. Такі права виникають 3 моменту набуття особою правового статусу судді (з моменту складення присяги). Зазначені права можуть бути статусними (право на відставку, право на участь у суддівському самоврядуванні, право на повагу професійної честі та гідності тощо) та функціональними (право на витребування доказів, право на окрему думку тощо).

Ключові слова: суддя, правовий статус судді, права судді, конституційна правосуб’ єктність.

Постановка наукової проблеми та її значення. Будучи пов'язаним між собою численними юридичними зв'язками, права та свободи суддів становлять основу їх правового статусу. Для висвітлення прав і свобод суддів варто зупинитися на загальній характеристиці їх основних груп, виходячи із традиційної для вітчизняної юридичної науки класифікації на громадянські (особисті), політичні, економічні, соціальні, культурні та інші. При цьому особливу увагу заслуговують права судді, що належать йому як людині і громадянину, але в рамках статусу судді набувають особливого змісту.

Аналіз досліджень цієї проблеми. Поняття та зміст прав суддів були і залишаються предметом дослідження багатьох вітчизняних і зарубіжних вчених, зокрема В. Веніславського, В. Єгорової, В. Єфанової, О. Калашник, С. Лаптєва, Л. Москвич, О. Намясенко, С. Подкопаєва, С. Прилуцького, О. Скрипнюка, О. Совгирі, В. Федоренка, В. Шаповала, Ю. Шемшученка, Д. Шпенова, І. Шруб, Т. Штих, Н. Шукліної, Н. Шульгач та інших.

Мета даної статті полягає у розкритті громадянських (особистих) прав суддів як складового елемента їх конституційної правосуб' єктності.

Виклад основного матеріалу й обгрунтування отриманих результатів дослідження. Одним з перших громадянських (особистих) прав людини, що закріплене Конституцією України $\epsilon$ право на вільний розвиток своєї особистості. Дане право закріплене у Декларації про право на

(C) Крвчук В., 2020 